\title{
Navigating democracy in America: a Virginia family's journey through the changing political and social landscape of the antebellum era
}

\author{
Randall S. Gooden
}

Received: 25 February 2018

Accepted: 12 June 2018

KEYWORDS: Goodwin family; literacy; slavery; United States history; Virginia history; War of 1812

\begin{abstract}
A sense of increased security in the aftermath of the War of 1812, a wave of economic expansion and opportunity, and a firmer sense of nation in the second generation of the United States combined to create a surge in democratic spirit. These trends keenly affected the state of Virginia, with its geographic position between the northern and southern regions and as a stepping-off point for westward expansion. The history of Virginia farmer and entrepreneur Thomas Goodwin and his family traces the ways in which an ordinary family navigated the changing political, social, and economic landscape with new opportunities for inclusion as well as obstacles to full participation in the evolving nation. For Goodwin, inclusion came with marriage into a rooted family with its ethnic connections to community, his military service, land ownership and the associated status as a freeholder, and the industriousness of him and his family. Yet, the Goodwins faced problems because of both old rules and institutions and new expectations in a society where expanded political participation meant increased responsibilities. These problems included ethnic prejudice, conflicts over slavery, and the disadvantages of illiteracy.
\end{abstract}

\section{Introduction}

In the aftermath of the War of 1812, Americans strived for a clearer meaning of nation and citizenship within it and for the prosperity which their new nation offered. The revolutionary generation had created the nation and citizenship and new opportunities for success, but it fell to the second generation to give a better definition of what it meant to be a republican nation and a citizen and of the path toward prosperity. With the economic, territorial, and demographic shifts that faced that generation, defining the nation, its citizens, and their opportunities became even more complicated.

It did not simply fall to the state and federal governments to declare the meaning of citizenship and bestow rights, privileges, and possibilities within the young nation. In American democracy, the potential of individuals depended upon their economic and social status in the eyes of the people around them. Not only that, the view which individuals had of their own relationship within their nation, state, and community influenced their perception of their personal power in politics, the economy, and society. Together, the attitudes of people toward one another and the opinion which individuals had of themselves determined how governments treated them and how they related to their governments.

In the shifting atmosphere of the early nineteenth century, Americans found it difficult to gauge their own power. As the nation found new security and prosperity after the War of 1812, the meaning of democracy changed and old markers of power fell away, only to be replaced by others. This was perhaps manifested most prominently in the changing markers for political participation. Writing in The Yale Law Journal, Jacob Katz Cogan has explained that Americans became "disillusioned with the adequacy of external characteristics," such as property and taxpayer qualifications and religious affiliation "as indicators of virtue" and "looked inward" to determine political worth. ${ }^{1}$ For some, the look inward brought the belief that this worth resided within every person - at least in every white male. Others looked inward but concluded that while everyone might be created equal, that did not mean that they were the same. Much of this notion centered on what Dayna L. Cunningham described as an "inevitable tension ... between the professed democratic principle of universal suffrage and the Jeffersonian aspiration that the electorate be highly educated and informed." ${ }^{2}$ Americans increasingly valued literacy and education, not just as a marker of power, but as necessary resources for participation in democracy and the increasingly complicated economy.

(0) 2018 The Author(s). This is an open access article distributed under the terms of the Creative Commons Attribution License (http://creativecommons.org/ licenses/by/4.0/) 
While the entire United States shifted politically, economically, and socially in its second generation of existence, the situation in mountain valleys of the state of Virginia - particularly the Shenandoah Valley - warrants a particularly close look. The valleys felt both tensions and compressions as they funneled migration into, through, and within them. Mere glances at the political maps of the region in the years between the War of 1812 and the Civil War reveal the effects of this migration as new counties formed and communities emerged. The surrounding mountains affected the ebb and flow of migration (see Figure 1). Torrents of change in economies and cultures occurred in some areas while at the same time pools of stagnation formed in others. All of this influenced the economic and social status of individuals in the eyes of others and the view which individuals had of their own relationship with their nation, state, and community.

The French political observer Alexis de Tocqueville saw in Americans a generally positive view of themselves in this time period. "In America, I have never met a citizen so poor that he did not cast a glance of hope and envy toward the pleasures of the rich or whose imagination did not anticipate the good things which fate stubbornly refused to him," he wrote. ${ }^{3}$ If hope, imagination, and anticipation motivated individuals to fulfill their dreams, the actions and reactions of those around them could just as easily interfere with those dreams. Pointing specifically to the Appalachian Mountains, the historian John Alexander Williams remarked, "A real-life backwoods family could just as likely have had different luck with land titles, the weather, illness, accidents, or other misfortunes." ${ }^{4}$

Like many in Virginia's mountain region, Thomas Goodwin "cast a glance of hope", only to have his hope dashed by "different luck." His family life is a microcosm of American society - poised between the north and south, east and west; between the prosperous and disadvantaged. In an era in which the American nation defined and redefined republican democracy and its benefits, qualifications, and responsibilities, Thomas Goodwin provides an archetypical case of a person who struggled to discover what his country had in store for him, how to obtain it, and what it expected from him. Such microcosms and archetypes allow study of broad national and regional trends and occurrences while providing the specificity which makes those trends and occurrences more humanly relevant. Informed by broader, scholarly historical study and contextualized by the history of place, family history offers a useful framework for such studies with its bridges across gender and generations and the humanistic detail which genealogical methods provide.

\section{"Riding on saddlebags and drinking grog"}

Born in Louisa County in Virginia's Piedmont in $1785,{ }^{5}$ Goodwin was among those whom Virginia patrician John Randolph - in lamenting the decline of society in the Old Dominion during the second generation of independence - described as "riding on saddlebags and drinking grog" $^{6}$. While a record exists of his birthdate, no record exists of Goodwin's parentage. He may have been a relative of the prominent Goodwin family who owned Oaksby Plantation in Louisa County - one of the most successful tobacco plantations of the region - though extant records make no connection. ${ }^{7,8,9}$ It seems just as likely that he was related to another Thomas Goodwin, a brief resident of Louisa County in the years after the American Revolution and distant relative of the Oaksby Plantation Goodwins, who took to the saddlebags and grog life after his father's estate - even the family Bible - was sold at auction. ${ }^{10}$ Then there was John Goodwin, a Louisa County resident who struggled throughout his life to acquire land and added to his ne'er-do-well reputation by trading and socializing with African Americans - both free and slave. ${ }^{11}$ Whatever was the case, Goodwin began life with no apparent inheritance.

Goodwin moved away from Louisa County and made a new home in Shenandoah County by the time he was twenty-four years old. Shenandoah County had achieved significance during the American Revolution as a center of iron production. The iron industry had boosted the county's mixed population of African American, English, German, and Scots-Irish heritage - as well as its prosperity. Among those who had come to Shenandoah County immediately after the revolution was the Hoffman family, descendants of Johannes Hoffman, who had come to Orange County in 1714 along with other Germans to establish an iron industry and man a defensive outpost at Germanna. Members of the family had arrived in Shenandoah County as early as 1762, and they were well established there when Thomas Goodwin arrived. ${ }^{12}$

One of the members of the family, Adam Hoffman, worked with Thomas Goodwin on a surveyor's crew. Together, they helped to survey land belonging to Adam's father, Daniel Hoffman, in 1811. The experience introduced Goodwin to the Hoffman family and eventually to the stable life that he sought as a farmer who owned his own land. ${ }^{13}$

Stability had to wait, however, as war threatened. While Goodwin was helping to survey lands between Virginia's Blue Ridge and Massanutten Mountains, the war that defined his generation began to brew. Ongoing difficulties between the United States and Great Britain unfolded into full-scale warfare in June 1812. President James Madison reluctantly called for war, and Congress obliged. Almost immediately, Virginians feared British attack from the sea, and the state responded by sending eight hundred militiamen to Norfolk in August to help guard the navy yard there. Shenandoah County reorganized its own militia and established new militia precincts, and Thomas Goodwin was placed in the ready forces. As a young, single man, 


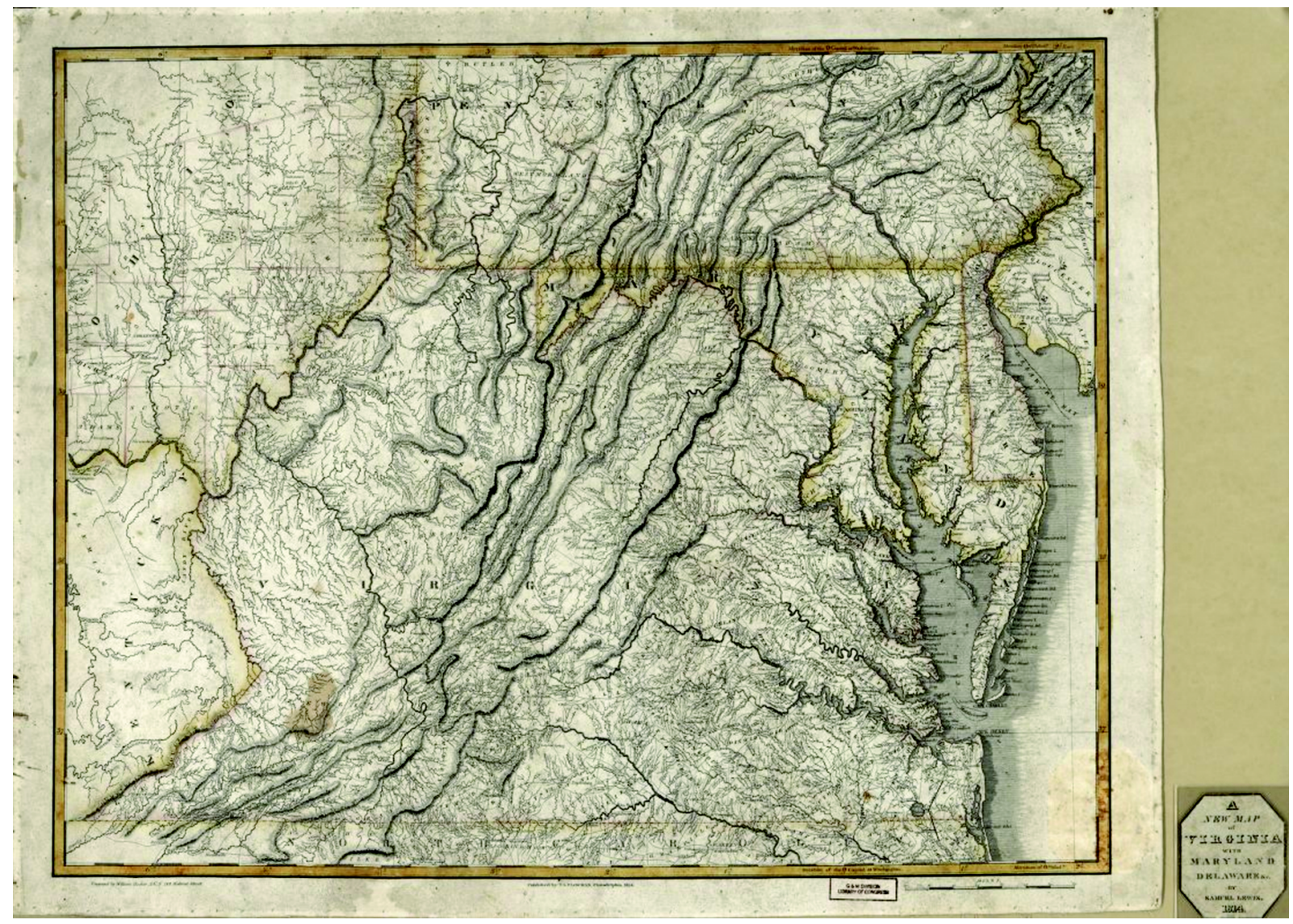

Figure 1. A map of Virginia as it appeared during the War of 1812 little resembled the state as it existed once westward expansion had been completed and the far western counties formed into the new state of West Virginia in $1863 .^{4}$

he could more easily leave his home for military duty. ${ }^{15,16}$ During the next year, events legitimized Virginia's fears. In June 1813, the British launched an all-out assault on Virginia. ${ }^{17}$ It was in this atmosphere that Thomas Goodwin received his call to active duty. Militia officers drafted him for six months during a muster at the village of Milford in Shenandoah County on 1 July 1813. Goodwin began his service in Captain Walter Hambaugh's rifle company, which consisted of men from Shenandoah County. ${ }^{18}$ Goodwin and his comrades depended upon the supplies that were available along the way as militia forces competed for supplies on their march toward the lower James River. ${ }^{19}$ In spite of an arduous journey, Hambaugh's company arrived at Camp Fairfield, near Richmond, by 20 August, and Goodwin drew his first pay as a private at eight dollars a month - money that he doubtless welcomed at the end of weeks of scarce supplies. Pay came irregularly, however. In most months it came late - as much as twenty-five days late, though the army paid the full amount that it owed. In September, Goodwin transferred to the command of Captain John Gilkeson of Frederick County and was stationed at Camp Holly, which guarded the river road approaches to Richmond. ${ }^{20}$

Uncertainty filled the lives of militiamen. "The system repeatedly left them unpaid, unarmed, unclothed, and adjusting to frequent changes in leadership," wrote historian Wayne E. Lee. ${ }^{21}$ Patriotism, a sense of urgency in the face of the enemy threat, and loyalty to neighbors in arms soon gave way to boredom, sickness, and frustration with bureaucracy. By 21 October Gilkeson's company arrived at Norfolk, where it helped to reinforce Fort Norfolk. For several weeks shortly after his arrival in Norfolk, Goodwin was sick. In this, he was not alone. Sickness and injuries led to the death of over eight percent of the American soldiers in the War of 1812. Nearly thirteen percent of the men in the U.S. Army reported as sick at some point in their service. ${ }^{22,23}$ The increase in militia forces at Norfolk seems to have discouraged the British from further attacks in that area, and they resorted to raids on the other side of Chesapeake Bay. Goodwin received his discharge on 10 January 1814 , and made his way back to the Shenandoah Valley, arriving before the full-scale British invasion of the Chesapeake region in August. ${ }^{24,25}$

While serving in the army, Goodwin first experienced confusion over his name. In an atmosphere of illiteracy, government officials often spelled individuals' names for them. Names often were spelled the way that they sounded to officials, or officials spelled the names the same as acquaintances with similar-sounding names. This had not mattered so much in past years when few written records were made or needed. However, in a nation with a growing and shifting population, the number of people with similar first and last names grew, and the need to 
distinguish between them through written records increased. Increasing ownership of land, an expanding role of government, and military service made government records more numerous for Americans, and the records became sources for confirming future rights and privileges. Incorrect records caused problems. In their book Illiteracy in America, Edward F. Dolan and Margaret M. Scariano pointed to this problem as they explained that difficulties were created not only by total and functional illiteracy but by cultural and professional illiteracy as well. The costs, according to Dolan and Scariano, were all at once economic, cultural, and political. ${ }^{26}$ In Thomas' case, militia officers listed his name as Goodwin at some times but wrote it as Goodin at other times. This discrepancy continued to plague him and his family for years to come as they sought veteran benefits. Further, throughout his life and beyond, Thomas and his family paid the costs of illiteracy. ${ }^{27}$

\section{Glancing at hope}

Goodwin returned to civilian life as a farmer, but also as a veteran who had contributed to the democracy which had given him the "glance of hope". While the war lasted, however, he and other farmers suffered from scarcity of specie, unstable banks, non-payment for military requisitions, inflation, and the effects of the British naval blockade on international markets. To add to their troubles, calls into the militia forced many of Thomas's neighbors in Shenandoah County to either leave their farms or pay up to $\$ 300$ for men to take their places in the drafts. ${ }^{28}$ Even after the war, economic troubles continued as a trade war with Great Britain, beginning in 1816, and a depression in 1819 hindered farm trade. ${ }^{29}$ Not everyone suffered during the war and its aftermath, however. The iron industry in the Shenandoah Valley experienced a boom. With its close proximity to Washington, the valley's iron was in high demand for the needs of the war. Land sales reflected this boom as advertisers emphasized the industrial and commercial amenities of land near Shenandoah Furnace, close to the Hoffman lands. The iron industry had spun off supporting industries - including a merchant mill, a fulling mill, and a saw mill, all of which promoted a mixed agricultural and industrial population. ${ }^{30}$ The boom also spurred road building, but Shenandoah Valley residents joined the national quest for internal improvements, not just to aid industry but to improve agricultural marketing. ${ }^{31}$ For Thomas Goodwin, the flourishing economy around the iron industry, the development of new roads, and gradually recovered postwar markets brought possibilities that he had not previously known in his first thirty years of life. He not only looked forward to better economic fortunes with the coming of peace but to a more stable personal life. Thomas's friendship with the Hoffman family had continued through the war and had led to a courtship with Susanna Hoffman, who was ten years younger than Thomas. On 13 March 1815 , Goodwin married Susanna at her home on South River, the South Fork of the Shenandoah River. ${ }^{32,33}$ Children came to the family the following year. Susanna bore her first child, Isaac, in April 1816 and two more sons, John and David, over the next three years. In the following decade, two daughters, Elizabeth and Mary, and another son, James (christened as Jacob), came along, and another daughter died shortly after birth. Three more sons and a daughter were born in the 1830 s (see Figure 2). ${ }^{34}$

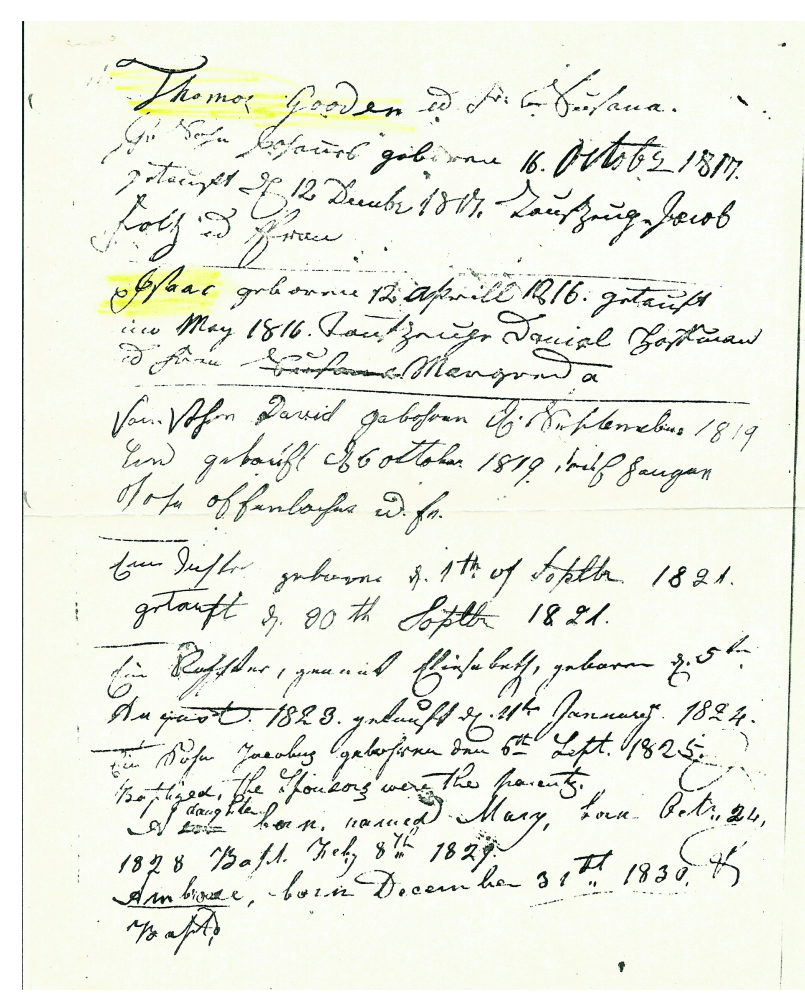

Figure 2. A facsimile of a baptismal record of St. Paul's Lutheran Church, written in German, showing Thomas and Susanna Goodwin's first seven children. 
As a young couple, the Goodwins became landowners in 1817. They purchased 150 acres and "appurtenances" from Jonas and Sairy (Sarah) Good for five hundred dollars "in hand." ${ }^{35,36}$ That advanced Thomas's (if not Susanna's) political power as well as his economic standing. With the purchase of the farm, Thomas became a freeholder under Virginia's 1776 constitution and was entitled to vote. The presence of their farm in a prime agricultural region of the country added to the Goodwins' economic standing. Historian William G. Slade has pointed to the economic struggles of Virginia's Tidewater and the undeveloped state of the trans-Allegheny region but described the Shenandoah Valley as a prosperous farm region:

\footnotetext{
The Great Valley of Virginia yielded a variety of grains besides wheat: rye, barley, buckwheat, and, in lesser amounts, oats and corn. Its fertile soil produced exceptional yields, and its farmers raised more hay than any other region, a sizable number of cattle, and one-third of that state's butter. Pigs and sheep were concentrated in the northern counties. While there were few planters in the Valley, the area was dominated by large and notoriously well kept farms. $^{37}$
}

\section{Exclusion and inclusion}

Thomas and Susanna's land adjoined that of Daniel and Margarett Hoffman on the South Fork of the Shenandoah River in an area known as River Hills or South River Hills. For Susanna, strong familial bonds and proximity to her family made it easy to participate in that society after her marriage. For Thomas, who seemed to lack roots of his own in the valley, the acceptance of his wife's family and his inclusion in their lives motivated him to generally follow German traditions.

It was not uncommon for family members to live near one another in the Shenandoah Valley, and the custom contributed to the concept of the Appalachian home place. The 1820 census shows many households with the same surnames within close proximity to one another. One traveler during the era attributed the tendency for many Shenandoah Valley families to live in close proximity to their German heritage and, reflecting his prejudices, referred to the custom as "land-mongering," a practice which increased the social and economic clout of a family. ${ }^{38}$

Inclusion in the dominant culture of the region benefitted the Goodwins locally, but it did have drawbacks in relations with broader Virginia society. In spite of the long presence of settlers of German descent in the Shenandoah Valley, they still experienced prejudice in the early 1800s. One nineteenth-century historian wrote, "The success of the Germans in agricultural, industrial and commercial pursuits, and their love of the old Fatherland ... increased the ill will of the Anglo-Virginians." He added, "the historian has to tell the truth and not gild dark clouds, and he must acknowledge that the Germans were politically and socially slighted." ${ }^{39}$ The comparative isolation of the upper reaches of the Shenandoah Valley tended to reinforce distinctions in culture, language and religion in the 1820s, whether intentional or not on the part of the region's residents.

The importance of family and ethnic community merged with religion as the Goodwin family grasped the hope for greater political, economic, and social standing. Thomas Goodwin's first known religious connections were with the Primitive Baptists, whose ministers had been persecuted in the Shenandoah Valley just a generation earlier. John Koontz, a pioneer Primitive Baptist minister and father of Thomas's regimental commander in the war, had married Thomas and Susanna. Nonetheless, the Hoffmans had been active in the German Reformed Church since arrival in Virginia in 1714, and after their marriage the Goodwins followed the Hoffman religious tradition. With no formal German Reformed meetinghouse in the vicinity, the family attended St. Paul Lutheran church, located between Grove Hill and Newport. German Reformed and Lutheran congregants often shared meetinghouses and even ministers as church buildings and ministers were scarce in the rural United States. ${ }^{40,41}$ So it was that the Goodwins and the Hoffmans associated themselves with St. Paul Lutheran church while they lived in the River Hills. Church records, written in German, show the young couple and their growing family in the 1820s. Interestingly, although their first eight children were baptized, Thomas and Susanna did not become communicants of St. Paul Lutheran church until $1826 .{ }^{42}$

During the Goodwins' association with St. Paul Lutheran church the religious revivalism of the Second Great Awakening spread southward into the Shenandoah Valley from the states of Maryland and Pennsylvania, reaching Woodstock, the county seat of Shenandoah County, in 1834. Although the revivalism mostly affected Presbyterian and Lutheran congregations in the county, as a whole the Lutherans discouraged revivalism. Conservatism and language barriers insulated German-speaking Lutheran congregations from the movement even further. ${ }^{43,44}$

Still, German-speaking churches were not immune from the revivalism. Its arrival into the region coincided with the appearance of other cultural influences from elsewhere. The internal improvements which brought economic opportunity also brought changes which challenged tradition. These challenges included the permeation of English-American culture into the German-American institutions of the Shenandoah Valley. Even in the German sects, English began to be heard more frequently. Traditionalists held onto the use of the German language in church meetings and recordkeeping in an effort to preserve their roots. "Germans were still in the majority, and they 
generally carried their point, but hundreds of young people drifted into the churches of the surrounding denominations, a fact which explains the origin of some of the strongest Methodist, Presbyterian and Episcopal congregations of present times," explains a historian of the Lutheran Church. ${ }^{45}$

In spite of the early anchor of the German-speaking church and culture in their lives, Thomas and Susanna appear among those who drifted. After 1830, they were not listed on the rolls of St. Paul church, and their last three children were not baptized. While they may have attended St. Peter's Lutheran church along Naked Creek, after they moved there in 1834, cultural ties seem to have changed for them in the 1830 s as they prospered and as the death of older family members loosened traditional bonds. Most dramatically, however, the family's eventual westward migration totally transformed their religious base as they joined with the Methodist Protestants in their new home in the far western part of the state. ${ }^{46}$

The Goodwins' religious life served as an anchor in their community and its power structures, but at times also reflected an acceptance of change in the post-War of 1812 nation. For Thomas Goodwin, change was not something which he sought as a constant, but which he viewed as a means to an end - stability and stature. Historian Daniel Walker Howe has explained the role of religion in bringing about stability from change. "The middle period of American history was a time of dramatic innovation - economic, moral, and institutional, as well as political," Howe wrote. "Far from being reactionary, as has sometimes been thought, the religion of the great revival was an engine driving rational change, a force for modernization." ${ }^{47}$

Cultural and economic flux gave rise to political restlessness for the community in which the Goodwins lived. This restlessness mixed with the nationwide redefinition of representative democracy which the entire nation experienced in the years following the War of 1812 and engulfed the Goodwins. These regional and national movements contributed to a growing sectional conflict between eastern and western sections of Virginia. Residents of the western part of the state winced at disproportionate representation that favored the regions east of the mountains, inadequate support for internal improvements, tax breaks for slave property, and the lack of popularly elected government offices.

The major point of contention, however, was the right to vote and hold political office. Many Virginians saw a connection between political participation and economic progress. In the years following the War of 1812, Virginia remained as only one of four states which still retained a freeholder qualification for voting. It required a voter to be a male citizen over the age of twenty-one and to own over fifty acres of unimproved land, over twenty-five acres of land with a house and farm, twenty-five dollars' worth of freehold land, or a house in a town. Reformers believed that these conservative requirements held the state back economically and politically. In the clamor to redefine democracy, the Shenandoah Valley became a focal point as representatives from a number of counties met in Harrisonburg in 1815 . They followed a trend set in other states and concluded that veterans and taxpayers should be allowed to vote, but did not advocate universal, white, male suffrage. In the following year, calls for a constitutional convention came from mass meetings at Winchester and Staunton. The state government made a few concessions to western Virginia in the form of support for internal improvements and new banks and reapportionment of the state senate, but the Panic of 1819 distracted the state from reform. By the mid 1820s, the people of the western portions of the state, including Shenandoah County, renewed their drive for a constitutional convention, and pockets of easterners joined them. Petitions and polls in 1824 and 1825 showed widespread support for constitutional reform among county voters. The state did not convene a constitutional convention, however. Instead, reformers from across the state convened at Staunton in 1825. Delegates insisted upon universal white, male suffrage and proportional legislative representation based on the white population. ${ }^{48-52}$

Pressure mounted after the Staunton Convention, and the state legislature finally called a constitutional convention in 1829 . The convention, meeting in Richmond, wrestled with the questions of eligibility to vote and hold government office. Positions ranged from holding the status quo in voting rights to extending suffrage to all white males over twenty-one. ${ }^{53}$ Conservatives insisted that property ownership meant reliability, accountability, and foresight and that those qualities were needed among voters. Property owners were vested in the economy and represented stable society. Richmond attorney and legislator Benjamin Watkins Leigh exemplified the conservatives when he declared, "Power and property may be separated for a time, by force or fraud - but divorced, never." Referring to a provision in the original Virginia Bill of Rights, Leigh contended, "The article enumerates property as equally dear and sacred with life and liberty, and as the principal means of happiness and safety - and with good reason - for, in order to live free and happy it is necessary that we live, and property is necessary to sustain life, and just as necessary to maintain liberty. ${ }^{\prime 54}$ Even some constitutional reformers associated property with successful democracy. Among them, John R. Cooke from Frederick County in the Shenandoah Valley observed that "he who has a strong desire to possess it, and a high relish, in anticipation, of the pleasure of enjoying it securely, will be a firm supporter of the laws which secure that possession, and a decided enemy of every systematic invasion of the rule of meum [mine] and tuum [thine]." ${ }^{55}$ Those who espoused universal, white, male suffrage pointed out that property owners alone did not provide support and stability to the state. Using the Goodwins' home county as an example, Alexander Campbell, a vocal proponent of expanded suffrage and proportional representation from Brooke County (nestled between the states of Ohio and Pennsylvania) focused on the contribution of soldiers in the War of 1812. "Yes, Sir, the single county of Shenandoah gave you twelve hundred men to fight your battles, or rather, the battles of their 
own State," Campbell noted. "And, Sir, the bones of many a gallant and brave citizen of the west, lie in the sands of Norfolk. Men, too, who had no suffrage, no representation in your Government, sacrificed not their property only, but their lives also, in your defence." ${ }^{56}$ Campbell did not advocate the extension of voting rights to veterans alone. He used military service as an example of the contributions and signs of stability, besides property ownership, which qualified citizens for equal political participation. For still others, no justification of the rights of suffrage seemed necessary. Non-freeholders from Shenandoah County simply petitioned for the right to vote without explanation. William Anderson, one of the county's delegates, presented their plea to the convention. ${ }^{57}$

The arguments over suffrage rights and the political worth of different classes of citizens placed Thomas Goodwin and his family between the contradictory pressures of history. On the one hand, Thomas had followed the conservative admonitions to acquire property, become a freeholder, and seek stability. On the other hand, he, like many of his neighbors, was not a member of the prosperous planter class, and he belonged to the class of veterans of which Alexander Campbell spoke. Along with his neighbors in the Shenandoah Valley, he identified with many of the interests of the mountainous western counties with its diverse economy, but at the same time, his region's economic and political ties with the east were indispensable.

The new constitution that came out of the convention disappointed reformers, including most of the people of Shenandoah County. It granted suffrage to all white, male heads of households, but it stopped short of universal suffrage, even among adult, white males. It provided for some reapportionment that favored Shenandoah Valley counties, but it failed to increase the number of elective offices. On either the state or local level, only state legislators were chosen by the voters. ${ }^{58}$ The new state constitution proved beneficial for the Shenandoah Valley in spite of the limited increase in voting rights. The region increased in political and economic influence. Partly because of the reapportionment, it gravitated toward the Piedmont counties in politics and pulled away from the trans-Allegheny counties. This new political affinity, combined with growing prosperity, increased the valley's political influence, and the state awarded it new internal improvements and more accessible local government. ${ }^{59}$ By 1831, plans for new internal improvements included a road between New Market and Culpeper, to the east of the Blue Ridge. Three years later, the Valley Turnpike Company was incorporated and began work on a macadamized highway between Winchester and Harrisonburg. Between 1832 and 1834, desires to connect the region with the Chesapeake and Ohio (C\&O) Canal along the Potomac River led to improvements on the Shenandoah River. The South Fork was made navigable as far as Port Republic in Rockingham County, and Newport, near the Goodwin and Hoffman lands, became a shipping point. ${ }^{60,61}$

More accessible local government came in 1831 with the creation of a new county from Shenandoah and Rockingham Counties. The state legislature created Page County, with its seat at Luray, and the Goodwins found themselves within its borders. This meant the reduction of the size and influence of Shenandoah County, but residents east of Fort and Massanutten Mountains had long petitioned for their own county because of political, economic, and cultural differences with the people in the broader valley of the North Fork of the Shenandoah. ${ }^{62,63}$ The internal improvements and accessibility to local government fueled the economy of the new county. "The new county of Page, for its extent, contains as much intrinsic wealth as any county west of the Blue ridge, with the exception of Jefferson," wrote regional historian Samuel Kercheval in $1833 .{ }^{64}$ Page County's farms and mills shipped wheat, flour, corn, oats, rye, potatoes, and wool down the river to the C\&O Canal. Iron producers marketed one thousand tons of cast iron in 1840 alone, and in the same year, the county stood on the verge of exporting lumber, timber, and coal to eastern cities. ${ }^{65}$

The Goodwins and Hoffmans benefitted from this growing economy. When Daniel Hoffman (written as Huffman in his will) died in 1833, his will indicated a prosperous farming and tanning business. He owned two tracts of land and left a third of his real estate, including the family home, to his wife, Margarett. She also received her choice of a horse, a saddle, bridle, cow, feather bed, and furniture. The rest of his land was divided among his three sons. In addition, the will bequeathed his tannery to his youngest son. Hoffman's sons were directed to provide a total of four hundred dollars to be divided among his four daughters, including Susanna Goodwin, two years after his death. ${ }^{66}$ In the year that Susanna inherited one hundred dollars from her father, her husband paid two hundred dollars to Jacob Conrad of Rockingham County for 150 acres of land. The couple sold their land on the South Fork of the Shenandoah River to Susanna's sister, Anna, and Stephen Price, Jr., and moved to their new farm on West Naked Creek, near the border between Page and Rockingham Counties. ${ }^{67,68}$

Over the next twelve years, Thomas and Susanna prospered with the mixed agricultural and industrial economy of the Shenandoah Valley, and their family expanded. In 1838, Margaret was born, and George came just eleven months later. Marriages followed among the older children. Isaac married Elizabeth Eppard, John married Irena Pence, and David married Judah Smith in 1841. James and Catharine Huffman exchanged vows in 1846. While their family grew Thomas and Susanna added to their property with the purchase of another $6613 / 4$ acres of land by 1842 . The value of their total holdings had risen from $\$ 300$ to $\$ 5,236$ over a ten-year period, and within five years, they built a new house, a new saw mill and a new barn. ${ }^{69-71}$

The Goodwins' prosperity belied a dichotomy in early nineteenth-century Virginia, however. Jacob Katz Cogan has pointed to an "interrelation of exclusion and inclusion" in the expansion of democracy. ${ }^{72}$ Although Thomas Goodwin was a freeholder and a voter as early as 1817 , it 
became apparent that the right to vote alone did not guarantee inclusion in democracy. His name appeared on a petition in 1834 for a new polling place to be created at Honeyville, across the river from his farm. The petition pointed out that the county seat at Luray was up to twenty-two miles away from the homes of some of the petitioners, and going to vote there required an overnight stay. The petition noted that a trip to Honeyville would be more convenient because many people went to George Kite's merchant mill or shopped at the store there. Just five years later, residents in the vicinity of Shenandoah Iron Works, just north of the mouth of Naked Creek, complained that the relatively new polling place at Honeyville was too far. Thomas joined them in a petition for a polling place to be created at the iron works. With the failure of that effort, Thomas and other freeholders on Naked Creek petitioned in 1840 for the creation of a polling place at George Price's mill. ${ }^{73}$

The politics of exclusion and inclusion affected the Goodwin family in other ways besides the struggle over the proximity of polling places. The politics of slavery entrapped the family in the 1840s. In 1840, 781 people labored as slaves in Page County. That number accounted for just under thirteen percent of the county's population. Many slaves worked on farms and in the small industries on the farms. A number worked as household servants, and still others worked in large industry. Not only did some industrialists employ their own slaves, but some slave owners sold the labor of slaves to owners of industries. ${ }^{74,75}$ Just three doors away from the Goodwins' farm, the firm D\&H Forrer used twenty-eight male slaves and three females at its iron furnace and forge. Five houses in the opposite direction, George Utz kept five women and girls and seven young men and boys as slaves on his farm. The interracial nature of the Naked Creek area did not just involve slavery, however. Within ten houses of the Goodwins, two free African American families, the Alexanders and the Setts, lived, and next to them, Caleb Francis, a white man, lived with an African American woman and children. Nearby, William Foster employed two African American men as free labor. Thus, with a mixture of slave-owning whites, whites who believed in free labor, free African Americans, and slaves in the area, relationships and expectations regarding race were complicated and tense. ${ }^{76}$

Part of those complications and tensions arose from paranoia over slave resistance and uprising. As early as 1798 , a slave allegedly killed his master in Shenandoah County. Six slaves were arrested and tried for sedition and attempted insurrection in the midst of war in 1814; the court sentenced one to be hanged and four to be whipped, and acquitted the sixth. In the atmosphere following Nat Turner's rebellion in 1831, two slaves in Page County were whipped for attacking white people, and one was banished from the United States for the same offense. In 1842 , two slaves in the county killed their master. ${ }^{77,78}$ To complicate matters, memories of anti-slavery agitation in Page and adjacent Rockingham County lingered from the early 1800 s. In the winter of 1845, slave owners in counties in the lower portions of the Shenandoah Valley, fearing abolitionist activity, held mass meetings to address news of white strangers mingling among slaves and called upon counties throughout the region to follow suit. ${ }^{79-81}$

The expectations of the community demanded restricted relations between whites and African Americans, and in 1845 Goodwin and his twenty-nine-year-old son, Isaac, violated those restrictions and separated themselves politically and socially from larger society. This happened when they conducted business transactions with slaves without their owner's consent. This constituted a state crime based on part of Virginia's slave code which had existed since 1748. The law's purpose was to discourage theft by slaves and to warn whites against encouraging independence among slaves. ${ }^{82-84}$ The county court tried the Goodwins, and a jury of three slaveholders and nine nonslaveholders found them guilty. The court fined Thomas fifty dollars and Isaac twenty dollars. The money went to the slave owner. It appears that Isaac was fined as an accessory to the transaction. ${ }^{85-87}$

\section{"A very illiterate man"}

By the end of the legal ordeal, Thomas was sixty years old. By most appearances, he and Susanna lived a comfortable life in a prosperous region. Their farm had grown in value since they had bought it. Not only did they produce crops and livestock, but they operated a saw mill, blacksmith shop, and two distilleries. As testimony of Thomas's role in the local socio-economic structure, one neighbor described him as a "hardworking, industrious man." ${ }^{88}$ Yet, ordinary people found it difficult to navigate the changing social and economic expectations which determined power and status, and economic mobility often belied weaknesses in a person's overall standing in society. Just as the Goodwins actively misstepped by conducting business with slaves, they passively misstepped as they tried to keep their place without literacy and education. The same neighbor who had praised Thomas's industry observed that "he had not much education - don't know if he could read or write." John Strole, a Justice of the Peace in the area, mentioned that Goodwin kept his accounts poorly and often relied upon his customers to make their own calculations. Strole explained that Thomas was "not simple but slow and sure." Though she was not as politically, socially, and economically exposed in antebellum Virginia because of illiteracy, Susanna could not read or write either. Likewise, the fact that the Goodwins' children had met the increasing demands of the era for literacy and education only slightly ameliorated the problem of Thomas's illiteracy. As head of the household, Thomas represented the family in its dealings within the patriarchal society of the times. Thus, the Goodwins paid the costs of illiteracy to which Dolan and Scariano referred. ${ }^{89}$

The Goodwins were not alone among Virginians in their lack of literacy and education. A "general societal ambivalence about literacy" existed in the antebellum south, according to literacy experts Edward E. Gordon and Elaine H. Gordon. "Across this landscape many people seemed to 
believe that a basic literacy education was not a necessary prerequisite for improving one's life," the Gordons have written, adding, "This 'literacy disenfranchisement' extended to most of the working classes." ${ }^{\prime 90}$

Nevertheless, the expectations of literacy and education were increasing by the mid 1800s across the United States, including the south. The expanding political participation which had characterized the Jacksonian age, and which Thomas embraced, coincided with increased needs for an educated and informed electorate. In that regard, the Appalachian frontier historian Otis K. Rice has commented, "The presence of large numbers of illiterate and ignorant citizens hardly offered a solid basis upon which to build the republican form of government or to effect the democratic processes so widely advocated during the Revolutionary era.. ${ }^{191}$ Indeed, as the Goodwins and others struggled with their illiteracy, democratic activists began calling for literacy and education requirements for voters and officeholders. One of the leading voices, Massachusetts attorney and legislator Samuel Jones, wrote in his A Treatise on the Right of Suffrage in 1842, "The general fact is, that persons wholly destitute of education do not possess sufficient intelligence to enable them to exercise the right of suffrage." ${ }^{\prime 22}$ The states of New Jersey and New York made constitutional allowances for literacy requirements in the 1840s, and Connecticut and Massachusetts put these recommendations into practice in the 1850 s by enacting literacy tests for voters, moves which historians attribute to efforts to limit voting by individuals of foreign birth. ${ }^{93}$

With these currents beneath the apparent stillness of success and maturity, the Goodwins left the Shenandoah Valley. On 28 August 1847 , they sold their house and outbuildings to Elijah Hamm for $\$ 80$. They sold 645 acres of their land to Rockingham County merchant and land dealer Richard Pickering for $\$ 6,000$ and 111 acres to Susanna's brother, Ambrose. Then, the Goodwins, minus Isaac and his family, departed Page County, and journeyed to a new home "in the West." ${ }^{\prime 94,95}$ The Goodwins chose the trans-Allegheny region as their destination. In this they were not alone. The War of 1812 generation was the critical period of development for that region, and eastern Virginia fueled the population growth in the western part of the state. Most Virginians, especially veterans of the war, stayed in their home state, and when they moved west, they tended to go to the Ohio Valley. The poor of the state and residents of the Shenandoah Valley and western sections accounted for most of Virginia's migrants. ${ }^{96}$

Thomas and Susanna moved to the Tygarts Valley river watershed, only 150 miles away from Naked Creek (see Figure 3). The Richmond Republican, in an 1846 article, promoted the Tygarts Valley and noted that "several substantial farmers from the East, instead of extending their vision to the 'Far West,' were looking, with the searching eyes of sensible men at the numerous advantages held out to prudent enterprise within this prolific valley."${ }^{\prime 97}$ The article listed the timber and mineral resources of the valley and surrounding mountains and extolled the grazing lands of the region. Construction of the Parkersburg and Staunton Turnpike had recently enhanced transportation from the Shenandoah Valley into the area. ${ }^{98}$

The Goodwins passed over the mountains and found their way to the Buckhannon river, a western tributary of the Tygarts Valley river, in territory then included in Lewis County. An 1849 article in the Winchester Virginian, reprinted in the Alexandria Gazette, described the country through which the family passed:

From the N. Western road to the Staunton and Parkersburg road, with the exception of Seneca, hardly an inlet is afforded. Scarce a horse-path, or cow-bell, relieves the horrible oppression of loneliness which seizes upon the traveller struggling to surmount the towering heights or casually lost in those dismal wilds. Here, until within a few years, the elk tossed his branched antlers, scarce startled by the report of some solitary rifle; and here, even now, is the feline cry of the panther heard, causing the benighted huntsman to creep nearer his fire as a security from the fears of that treacherous, but cowardly beast. ${ }^{100}$

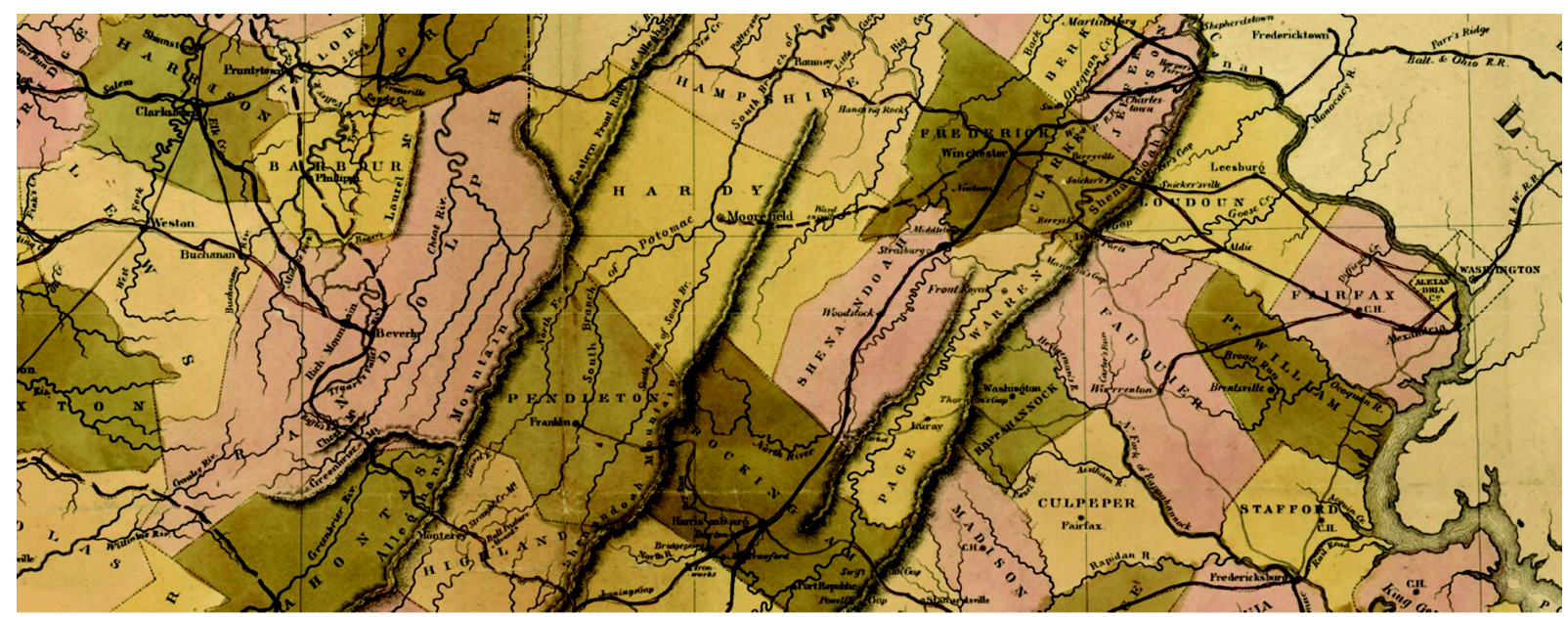

Figure 3. A portion of an 1848 map of Virginia showing Shenandoah and Page Counties and the area to the west where the Goodwins eventually settled. ${ }^{99}$ 
Thomas and Susanna's move to Lewis County brought new changes to the family makeup. They had already left Isaac and his wife and children and Susanna's relatives behind. Now, more changes came in the new country. When they arrived, they lived near William Goodwin, an early settler in the region and a member of Thomas's generation. Perhaps Thomas and William were brothers or cousins. At any rate, one of William's sons, Elijah Goodwin, later appeared as a witness to Susannah's signature on legal documents, and a grandson of Thomas and Susanna was named Elijah. Often, American migrants to new lands joined relatives who had gone before them, and this appears to be the case for the Goodwins. Within the immediate family, Mary married Peter Zickefoose and soon had a little girl. John and his wife and three children moved farther west to the state of lowa by $1850 .^{101,102}$

Upon their arrival in western Virginia, Thomas and Susanna lived on land belonging to others, and Thomas worked at times for other farmers, but by 1850 , they had moved to their own land, one thousand acres of mostly forested acreage, in nearby Randolph County. Their sons Ambrose, Thomas, and George and their daughters Elizabeth and Margaret lived with them. James and David and their young families farmed land on either side of them. However, within a few years David followed John to lowa. Within two years, Thomas and Susanna themselves experienced another change of counties, without moving an inch. The state government formed a new county, Upshur County, from the portion of Randolph County where they lived and from the portion of Lewis County where they had previously lived, as well as from part of Barbour County. ${ }^{103-105}$

With Thomas and Susanna's move to the west, financial problems followed. They had purchased their land on Naked Creek on a promissory note, and still owed money on it when they left. An unexpected boon came to Thomas, however, ironically, from a war in which neither he nor his sons had fought. Congress, in 1847, had authorized land bounties for veterans of the Mexican War. As it turned out, those bounties proved more generous than those that had been given to the veterans of the War of 1812. The law stipulated that veterans of the earlier war had to have served five years in order to obtain land. Angry survivors of the War of 1812 began lobbying the federal government, and Congress felt the pressure. In 1850, a new law provided land to all men who had served for at least one month in the military after 1790 . The law was ambiguous about whether the land warrants could be sold, and the commissioner of bounty lands would not allow the 1812 veterans to sell their land. This meant that, in order to accept the bounties, these older men and their families had to move to the land, which was often far distant from their homes. To add insult to injury, Mexican War veterans could sell their land grants. ${ }^{106}$ In spite of the limitations of the law, with the assistance of a Washington attorney, Thomas applied for a bounty warrant in 1851, and early in 1852 received eighty acres in Lewiston Township, Columbia County, in the state of Wisconsin. Fortunately for Goodwin, a change in the law that year allowed him to sell the land. He sold the land to Isaac Andrews, "in whose farm said tract has been located." According to The History of Columbia County, Wisconsin, the federal government had not surveyed its lands in the township until 1851, and by that time farmers, including Andrews, had settled on them. Although the government gave the squatters the opportunity to claim pre-emptive rights, Andrews had not done so before Goodwin received the land. So, Thomas sold the property to him. ${ }^{107-109}$

While Thomas struggled to make the future secure for his family, the War of 1812 generation was coming to an end in the 1850s, and Thomas's own life ended in 1853. Typhoid fever swept the community that fall. Daughter Mary's husband died from the disease, and Thomas succumbed three days later. ${ }^{110}$ Thomas's death left the family teetering, and Susanna lost her balance. Her husband died without a will, and under Virginia's patrician laws, most of Thomas's farm and his personal property were sold at auction. The law allowed Susanna to keep only the homestead and enough flour and cornmeal to sustain her and her younger children. Adult children and friends restored some of her former life when they bought personal items that had belonged to Thomas and returned them to her. James bought a portion of his father's land. ${ }^{111}$

While Susanna was still dealing with Thomas's death, troubles from Page County surfaced. In the year that Thomas died, Richard Pickering, to whom he had sold a portion of his land on Naked Creek, named him in a lawsuit over ownership of a part of the land. Naked Creek formed the boundary of the property, and the dispute revolved around a small island in the middle of the creek. Possession of the island meant control of waters that Pickering needed for a mill race. Besides Thomas Goodwin, Pickering listed Henry Miller, from whom Thomas had bought the land, in the suit. ${ }^{112}$ When the case reached the attention of the Goodwins in Upshur County, Susanna turned to William Bennett, administrator for Thomas's estate. In his affidavit in the case, Bennett expressed his confidence in Thomas's innocence in the matter and suggested that if any wrong had occurred, that Thomas had been duped. While the Goodwins' move to the trans-Allegheny region had placed them in a remote area among people of comparable educational level, they did not escape the increasing expectations of literacy in American society (see Table 1). Bennett concluded that Thomas had been vulnerable in land transactions because "he was a very illiterate man," and those vulnerabilities continued to haunt his family after his death. ${ }^{13}$

Meanwhile, George H. Dameron, a neighbor of the Goodwins in Upshur County, sued Pickering. After Thomas had moved into the area, he had sold to Dameron two promissory notes, for five hundred dollars each, which Pickering had given to Goodwin for the purchase of his property. Pickering had agreed to pay the first note by October 1852 and the second one by October 1853 and had not done so. The county court in Page County placed a lien against Pickering's personal property until the debt was paid, but Pickering challenged the ruling on the basis that a portion of the land involved was in dispute. ${ }^{114}$ Residents of the Naked Creek community gathered at Ambrose Hoffman's store to give depositions in the case. Differing opinions about whether Goodwin intended to sell the disputed land rested on recollections of whether he had used the property for his stills. One 
deponent, George Morica, the sheriff of Page County, showed Thomas Goodwin to be a man who cautiously avoided complications with the world around him. Morica recalled that a tree had once fallen on the island in Naked Creek and that the Goodwin sons had wanted to cut up the tree for

Table 1. Comparison of illiteracy in Page and Randolph Counties in $\mathbf{1 8 5 0}$

\begin{tabular}{|c|c|c|c|c|c|c|c|c|c|c|}
\hline \multirow[b]{2}{*}{ Location } & \multirow[b]{2}{*}{$\begin{array}{l}\text { Total adult } \\
\text { illiteracy }\end{array}$} & \multirow[b]{2}{*}{$\begin{array}{l}\text { Illiteracy } \\
\text { among men }\end{array}$} & \multirow[b]{2}{*}{$\begin{array}{l}\text { Illiteracy } \\
\text { among women }\end{array}$} & \multicolumn{3}{|c|}{$\begin{array}{c}\text { Adult illiteracy by } \\
\text { generation }\end{array}$} & \multirow[b]{2}{*}{$\begin{array}{l}\text { Illiteracy among } \\
\text { landowners }\end{array}$} & \multicolumn{3}{|c|}{ Illiteracy by occupation } \\
\hline & & & & $18-35$ & $36-65$ & $66+$ & & $\begin{array}{l}\text { Business/ } \\
\text { Crafts People }\end{array}$ & Farmers & Laborers \\
\hline Page County & $25 \%$ & $10 \%$ & $41 \%$ & $20 \%$ & $22 \%$ & $50 \%$ & $17 \%$ & $0 \%$ & $5 \%$ & - \\
\hline Randolph County & $42 \%$ & $27 \%$ & $54 \%$ & $43 \%$ & $45 \%$ & - & $40 \%$ & $0 \%$ & $30 \%$ & $67 \%$ \\
\hline
\end{tabular}

wood. According to the sheriff, Thomas had objected because he "had no interest in it" and that someday "it might raise a rumpus." ${ }^{115,116}$ In the end, the circuit court in Page County decided against Pickering in both of his cases. The result hinged on the fact that the course of the creek channel, known as "the gut", that formed the property line in question had changed over the years because of flooding. ${ }^{117,118}$

\section{Conclusion}

Thomas's death and the legal turmoil of the 1850s put his family over the edge legally and financially, but it marked the beginning of the Civil War generation as the family and other Virginians fell into the darkness of the sectional gulf. Virginia struggled in 1853 as the western portion demanded a greater influence in state government - despite state constitutional changes the previous year which made more state and local offices elective and granted proportional representation in the lower house of the legislature. At the same time the eastern portion insisted upon the superiority of its economic and political role - a role that depended on slavery. The place where the Goodwins lived was a scene in this struggle. Like the residents of the Shenandoah Valley, the people pursued a mix of agriculture and industry. However, slavery had never taken root in the Buckhannon and Middle Fork river regions. Slaves made up only about 3.7 percent of the population - partly because of the smaller farms of the mountains and narrower valleys, partly due to its geographic affinity with Ohio and Pennsylvania, and partly because large numbers of New Englanders had settled along the Buckhannon river in the early 1800 s and instilled their anti-slavery attitudes in their children. ${ }^{119,120}$

When the Civil War erupted, Upshur County supported the United States by a ratio of about three to one. Ambrose and George Goodwin ended up on the Union side of the Civil War. The loyalties of their brother, Thomas, are uncertain. James sympathized with the Confederate States. Isaac's son, George, in the Shenandoah Valley, served in the Confederate Army and was wounded at the Battle of Chancellorsville. The record of the lowa Goodwins in the war remains unclear, but Davis County, where they lived, supported the United States. ${ }^{121-123}$

Susanna Goodwin, sixty-nine years old when the war ended, depended upon her children and lived with her youngest son, George, as he married, lost his wife, and then remarried. Money was scarce, and Susanna once again turned to her husband's war record in an attempt to get a pension. Just as the Mexican War had given some political crumbs to War of 1812 veterans, the unprecedented influence of Civil War veterans in American politics had led to a revived awareness of still older veterans and their widows. Susanna took advantage of a new pension law and, with the help of an attorney, applied for a widow's pension and received it. ${ }^{124,125}$

Susanna died in $1881 .{ }^{126}$ She was eighty-five years old. Sixty-six years had passed since she and Thomas had been married. In the years between, the Goodwins had glanced at hope. Land ownership had given them a chance for prosperity and had given Thomas the right to vote. His record as a veteran had granted him social and suggested political status and still more land. He had witnessed the extension of suffrage to more and more neighbors and had joined them to demand better access to local government and the polls. The Goodwins had basked in the comfort of family and their German-American culture and religion in the relative isolation of the Virginia mountains and yet had opened themselves to the economic prosperity of the valley which nestled among those mountains and led to the markets of the east coast. Figure 4 shows the family tree.

Still, different luck, as John Alexander Williams called it, marred the hopes. Land ownership brought debt and boundary disputes, which ended up in the courts which seemed more readily accessible, ironically as a result of expanding democracy. Prosperity increased the consciousness of money and fueled a litigious atmosphere which ensnared the Goodwins. Increasing democratic struggles over sectional rights and slavery caused stubborn counter-reactions against change, and in the case of slavery, the Goodwins suffered when they challenged the status quo. The family culture and isolation which sheltered the family also restricted its adaptation to the world around it, and when the Goodwins found greater isolation farther to the west, this simply removed the family from the mainstream of society and the economy rather than offering protection. All of these challenges, though, were exacerbated by lack of literacy and education - expectations in order to navigate the vast political, societal, and economic landscape of the nineteenth-century United States. 


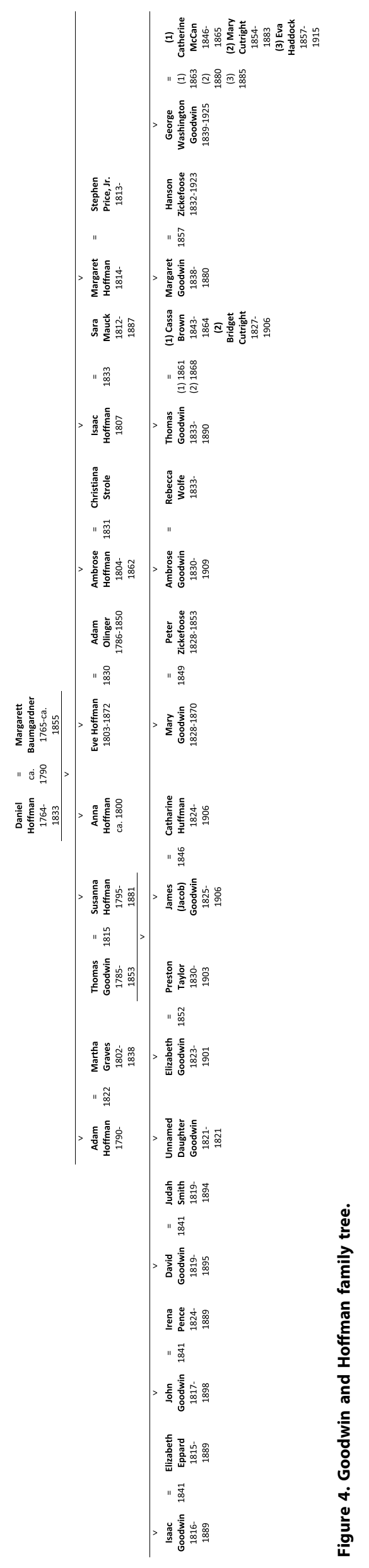




\section{Citation information}

Cite this article as: Gooden, Randall S. (2018) Navigating democracy in America: a Virginia family's journey through the changing political and social landscape of the antebellum era. Journal of Genealogy and Family History. 2(1). pp. 53-66. http://dx.doi.org/10.24240/ 23992964.2018.1234515

\section{References}

1. Cogan, Jacob Katz. (1997) The look within: property, capacity, and suffrage in nineteenth-century America. The Yale Law Journal. 107(2). pp. 477, 482.

2. Cunningham, Dayna L. (1991) Who are to be the electors? A reflection on the history of voter registration in the history of the United States. Yale Law and Policy Review. 9(2). p. 370

3. de Tocqueville, Alexis. (2003) Democracy in America and two essays on America. New York: Penguin Books. p. 617

4. Williams, John Alexander. (2002) Appalachia: a history. Chapel Hill: University of North Carolina Press. p. 90.

5. Family Bible in possession of George A. Gooden, Queens, W.V.

6. Hamilton, Phillip. (2003) The making and unmaking of a revolutionary family: the Tuckers of Virginia, 1752-1830. Charlottesville: University of Virginia Press. p. 147.

7. Goodwin, Judge John S. (1897) The Goodwin families in America. William and Mary College Quarterly Historical Magazine. 6(2). pp. 1-58.

8. Harris, Malcolm Hart. (1963) History of Louisa County, Virginia. Petersburg, Va.: Dietz Press.

9. Family Bible in possession of George A. Gooden.

10. Revolutionary War Pension and Bounty-Land Warrant Application Files, 1800-1900. http://www.ancestry.com

11. Louisa County Personal Property Tax Lists. Library of Virginia, Richmond, USA

12. Wayland, John W. (1927) A history of Shenandoah County, Virginia (reprint). Baltimore: Regional Publishing Co. p. 8.

13. Virginia, County of Shenandoah, Surveyor. Surveyor's Book, 1794-1817. Office of Shenandoah County Clerk, Woodstock, Va.

14. Lewis, Samuel and Hooker, William. (1814) A new map of Virginia with Maryland Delaware \& v. Philadelphia: T. L. Plowman. http://hdl.loc.gov/loc.gmd/g3790. ct004097. Original held by Library of Congress, Geography and Map Division.

15. Commonwealth of Virginia, Virginia Bicentennial of the War of 1812 Commission. Virginia Bicentennial of the War of 1812 Commission. http://va1812bicentennial.dls. virginia.gov/.

16. Virginia, County of Shenandoah, County Court. Minute Book, 1810-16, Office of Shenandoah County Clerk, Woodstock, Va.

17. Commonwealth of Virginia, Virginia Bicentennial of the War of 1812 Commission. Virginia Bicentennial of the War of 1812 Commission. http://va1812bicentennial.dls. virginia.gov/.

18. Department of Interior (USA). Bureau of Pensions, War of 1812 Pension Application Files. Record Group 15, National Archives and Records Admin., Washington, D.C.

19. The Enquirer (Richmond). (1814) The Enquirer. 4 May

20. Department of Interior (USA). Bureau of Pensions, War of 1812 Pension Application Files. Record Group 15, National Archives and Records Admin., Washington, D.C.

21. Lee, Wayne E. (2001) Early American ways of war: a new reconaissance, 1600-1815. The Historical Journal. 44. p. 287.

22. Department of Interior (USA). Bureau of Pensions, War of 1812 Pension Application Files. Record Group 15, National Archives and Records Admin., Washington, D.C.

23. Stagg, J. C. A. (1986) Enlisted men in the United States Army, 1812-1815: a preliminary survey. The William and Mary Quarterly. 43(4). p. 624.

24. Department of Interior (USA). Bureau of Pensions, War of 1812 Pension Application Files. Record Group 15, National Archives and Records Admin. Washington, D.C.

25. Commonwealth of Virginia, Virginia Bicentenial of the War of 1812 Commission. Virginia Bicentennial of the War of 1812 Commission. http://va1812bicentennial.dls. virginia.gov/.

26. Dolan, Edward F. and Scariano, Margaret M. (1995) Illiteracy in America. New York: Franklin Watts. pp. 12-14, 18-21.

27. Department of Interior (USA). Bureau of Pensions, War of 1812 Pension Application Files. Record Group 15, National Archives and Records Admin., Washington, D.C.

28. [No author] (1900) Richmond during the War of 1812 (continued). Virginia Magazine of History and Biography. 7(4). p. 411

29. Haulman, Clyde (2002) Virginia commodity prices during the panic of 1819. Journal of the Early Republic. 22. pp. 676-79.

30. Alexandria Gazette. (1812-1814). Alexandria Gazette. passim.

31. Wayland, John W. (1927) A history of Shenandoah County, Virginia (reprint) Baltimore: Regional Publishing Co. pp. 12-13.
32. Vogt, John and Kethley, T. William. (1984) Shenandoah County marriage bonds 1772-1850. Athens, Ga.: Iberian Press. p. 170

33. Department of Interior (USA). Bureau of Pensions, War of 1812 Pension Application Files. Record Group 15, National Archives and Records Admin., Washington, D.C.

34. Family Bible in possession of Julia M. Wright, Wharton, Texas.

35. Virginia, Clerk of County Court, County of Shenandoah. Deed Book Y. Office of Shenandoah County Clerk, Woodstock, Va.

36. Census. 1820. USA. United States Federal Census. http://www.ancestry.com.

37. Shade, William G. (1996) Democratizing the Old Dominion: Virginia and the second party system, 1824-1861. Charlottesville, Va.: University Press of Virginia. p. 34

38. Census. 1820. USA. United States Federal Census. http://www.ancestry.com

39. Schurict, Herrmann. (1898) History of the German element in Virginia. Baltimore: T. Kroh \& Sons. p. 37

40. Wayland, John W. (1927) A history of Shenandoah County, Virginia (reprint) Baltimore: Regional Publishing Co. pp. 170, 254, 439.

41. Good, James I. (1911) History of the Reformed Church in the U.S. in the nineteenth century. New York: Board of Publication of the Reformed Church in America. pp. 182-186.

42. St. Paul's Lutheran Church. Records, Farmers and Merchants Bank. Shenandoah, Va.

43. Good, James I. (1911) History of the Reformed Church in the U.S. in the nineteenth century. New York: Board of Publication of the Reformed Church in America. pp. 130-138.

44. Neve, J. L. (1916) A brief history of the Lutheran Church in America. $2^{\text {nd }}$ rev. and enlarged ed. Burlington, la.: German Literary Board. pp. 110-111.

45. Neve, J. L. (1916) A brief history of the Lutheran Church in America. $2^{\text {nd }}$ rev. and enlarged ed. Burlington, la.: German Literary Board. pp. 82-83.

46. Virginia, County of Upshur. Marriage Register. Office of Clerk of County Court, Buckhannon, W.V.

47. Howe, Daniel Walker. (1991) The evangelical movement and political culture in the north during the second party system. The Journal of American History. 77(4). p. 1239.

48. Peterson, Merrill D., ed. (2010) Democracy, liberty, and property: the state constitutional conventions of the 1820s. Indianapolis: Liberty Fund. pp. 178, 183-184.

49. Library of Virginia, Richmond, Va. (USA). Citizens: Petitions, Legislative Petitions of the General Assembly 1776-1865. Virginia Memory, Library of Virginia, Richmond. http://www.virginiamemory.com/collections/petitions.

50. Library of Virginia, Richmond, Va. (USA). Citizens: Polls, Legislative Petitions of the General Assembly 1776-1865. Library of Virginia, Richmond. http://www.virginia memory.com/collections/petitions.

51. Shade, William G. (1996) Democratizing the Old Dominion: Virginia and the second party system, 1824-1861. Charlottesville, Va.: University Press of Virginia. pp. 58-61.

52. Genius of Liberty. (1825) Fairfax election, for the Genius of Liberty. Genius of Liberty. Leesburg, Virginia. 26 April. pp. 2-3.

53. Shade, William G. (1996) Democratizing the Old Dominion: Virginia and the second party system, 1824-1861. Charlottesville, Va.: University Press of Virginia. pp. 58-61.

54. Peterson, Merrill D., ed. (2010) Democracy, liberty, and property: the state constitutional conventions of the 1820s. Indianapolis: Liberty Fund. pp. 300, 308.

55. Peterson, Merrill D., ed. (2010) Democracy, liberty, and property: the state constitutional conventions of the 1820s. Indianapolis: Liberty Fund. p. 272.

56. Peterson, Merrill D., ed. (2010) Democracy, liberty, and property: the state constitutional conventions of the 1820s. Indianapolis: Liberty Fund. p. 123

57. [No author] (1830) Proceedings and debates of the Virginia State Convention of 182930. Richmond: Ritchie \& Cook. p. 32

58. Shade, William G. (1996) Democratizing the Old Dominion: Virginia and the second party system, 1824-1861. Charlottesville, Va.: University Press of Virginia. p. 70

59. Shade, William G. (1996) Democratizing the Old Dominion: Virginia and the second party system, 1824-1861. Charlottesville, Va.: University Press of Virginia. pp. 70-77.

60. Silvius, Don. The Valley Turnpike. Shenandoah County GenWeb Project. http://www vagenweb.org/shenandoah/cem/turnpike.html.

61. Wayland, John W. (1912) A history of Rockingham County. Dayton, Va.: RuebushElkins Co. pp. 421-422.

62. Genius of Liberty. (1831) Virginia legislature. Genius of Liberty. Leesburg, Virginia. 9 April. p. 2.

63. Library of Virginia, Richmond, Va. (USA). Legislative Petitions of the General Assembly 1776-1865. Virginia Memory, Library of Virginia, Richmond. http:// www.virginiamemory.com/collections/petitions.

64. Kercheval, Samuel. (1833) History of the Valley of Virginia. Winchester: Samuel H. Davis. p. 453

65. Strickler, Harry Miller. (1952) A short history of Page County. University of Virginia: Dietz Press. p. 409

66. [Testamentary records.] USA. 1833. HUFFMAN, Daniel. Virginia, County of Page, Clerk of the County Court. Will Book A. Office of Page County Clerk, Luray, Va. 
67. Virginia, County of Page, Clerk of the County Court. Deed Book D. Office of Page County Clerk, Luray, Va.

68. Virginia, County of Page, Clerk of the County Court. Land Book, 1840. Office of Page County Clerk, Luray, Va.

69. Family Bible in possession of Julia M. Wright.

70. Virginia, County of Page, Clerk of the County Court. Deed Book D. Office of Page County Clerk, Luray, Va.

71. Virginia, County of Page, Clerk of the County Court. Land Book, 1842, 1846 and 1847. Office of Page County Clerk, Luray, Va.

72. Cogan, Jacob Katz. (1997) The look within: property, capacity, and suffrage in nineteenth-century America. The Yale Law Journal. 107(2). p. 473.

73. Legislative Petitions of the General Assembly.

74. Strickler, Harry Miller. (1952) A short history of Page County. University of Virginia: Dietz Press. p. 138

75. Census. 1840. USA. United States Federal Census. http://www.ancestry.com.

76. Census. 1840. USA. United States Federal Census. http://www.ancestry.com.

77. Wayland, John W. (1927) A history of Shenandoah County, Virginia (reprint) Baltimore: Regional Publishing Co. p. 252.

78. Strickler, Harry Miller. (1952) A short history of Page County. University of Virginia: Dietz Press. pp. 134, 160-161.

79. Mill Creek Church (Mauck Meeting House) http://www.pipeline.com/ richardp ence/millcreek.htm.

80. Wayland, John A. (1907) German element of the Shenandoah Valley. Charlottesville, Va.: Author. p. 181

81. Spirit of Jefferson. (1845) Spirit of Jefferson, Charles Town, Virginia. 6 February. p. 1.

82. Virginia, County of Page, County Court. Order Book. Virginia State Library, Richmond.

83. Guild, June Purcell. (1936) Black laws of Virginia. a summary of the legislative acts of Virginia concerning Negroes from earliest times to the present. New York: Negro Universities Press. http://www.racetimeplace.com/ugrr/slavelawsofvirginiasince1705.htm.

84. Farnam, Henry Walcott. (2007) Chapters in the history of social legislation in the United States. Clark, N.J.: Lawbook Exchange. p. 191.

85. Virginia, County of Page, County Court. Order Book, Virginia State Library, Richmond.

86. Census. 1840. USA. United States Federal Census. http://www.ancestry.com.

87. Virginia, General Assembly. (1808) Acts of the General Assembly of Virginia of a public and permanent basis as have passed since 1801 to which are added appendices. Richmond: Samuel Pleasants, Jr. p. 229.

88. Chancery File Index (USA). Pickering v. Dameron et al. Virginia Memory, Library of Virginia, Richmond. http://www.Iva.virginia.gov/chancery/full_case_detail.asp? CFN=139-1855-003\#img

89. Chancery File Index (USA). Pickering v. Dameron et al. Virginia Memory, Library of Virginia, Richmond. http://www.Iva.virginia.gov/chancery/full_case_detail.asp? CFN=139-1855-003\#img.

90. Gordon, Edward E. and Gordon, Elaine H. (2003) Literacy in America: historic journey and contemporary solutions. Westport, Ct.: Praeger. p. 135.

91. Rice, Otis K. (1970) The Allegheny Frontier: West Virginia Beginnings, 1730-1830 University Press of Kentucky. p. 214.

92. Jones, Samuel (1842) A treatise of the right of suffrage, with an appendix. Boston: Otis, Broaders and Co. p. 132.

93. Branch, Kirk. (2015) 'A mockery in the name of a barrier': literacy test debates in the Reconstruction Congress, 1864-1869. Literacy in Composition Studies. 3(2). pp. 44-65.

94. Virginia, County of Page, Clerk of the County Court. Deed Book G. Page County Clerk's Office, Luray, Va.

95. Virginia, County of Page. Land Book, 1848. Office of Page County Clerk, Luray, Va. 96. Oberly, James W. (1986) Westward who? Estimates of native white interstate migration after the War of 1812. Journal of Economic History. 46 (2). pp. 432-3, 435-6, 438.

97. Alexandria Gazette. (1846) Western Virginia. Alexandria Gazette. 14 September. p. 2.

98. Alexandria Gazette. (1846) Western Virginia. Alexandria Gazette. 14 September. p. 2.

99. Crozet, Claudius. (1848) A map of the internal improvements of Virginia; prepared by $C$. Crozet, late principal engineer of $V a$. under a resolution of the General
Assembly adopted March 15th 1848. Philadelphia. http://hdl.loc.gov/loc.gmd/ g3880.rr003070. Original held by Library of Congress, Geography and Map Division.

100. Alexandria Gazette. (1849) Randolph County, Virginia. Alexandria Gazette. 23 November. p. 2.

101. Department of Interior (U.S.). Bureau of Pensions, War of 1812 Pension Application Files. Record Group 15, National Archives and Records Admin., Washington, D.C.

102. Interview with George A. Gooden, Queens W.V., August 1968

103. U.S., Bureau of Census, Population Schedules, 1850 and 1860

104. Interview with George A. Gooden, Queens W.V., August 1968.

105. Cutright, W. B. (1907) The history of Upshur County, West Virginia from its earliest exploration and settlement to the present time. Buckhannon, W.V.: Author. p. 63.

106. Oberly, James W. (1985) Gray-haired lobbyists: War of 1812 veterans and the politics of bounty land grants. Journal of the Early Republic. 5(1). pp. 35-36.

107. Oberly, James W. (1985) Gray-haired lobbyists: War of 1812 veterans and the politics of bounty land grants. Journal of the Early Republic. 5(1). p. 36.

108. General Land Office (USA). Patent 25314, Volume 355. National Archives and Records Admin., Washington, D.C.

109. [No author] (1880) The History of Columbia County, Wisconsin. Chicago: Western Historical Co. pp. 764-765.

110. Deaths (CR) USA. Upshur County, West Virginia. 10 May 1853. GOODIN, Thomas. Upshur County, Clerk of the County Court. Register of Deaths. Office of County Clerk, Upshur County Courthouse, Buckhannon, W.V.

111. Virginia, County of Upshur, Clerk of the County Court. Deed Book C. Office of Upshur County Clerk, Buckhannon, W.V.

112. Chancery File Index (USA). Pickering v. Miller et al. Virginia Memory, Library of Virginia, Richmond. http://www.lva.virginia.gov/chancery/case_detail.asp?CFN= 139-1853-013.

113. Chancery File Index (USA). Pickering v. Miller et al. Virginia Memory, Library of Virginia, Richmond. http://www.Iva.virginia.gov/chancery/case_detail.asp?CFN= 139-1853-013.

114. Chancery File Index (USA). Richard Pickering, Sr. v. G. H. Dameron et al. Virginia Memory, Library of Virginia, Richmond. http://www.lva.virginia.gov/chancery/case_ detail.asp?CFN=139-1853-013.

115. Chancery File Index (USA). Richard Pickering, Sr. v. G. H. Dameron et al. Virginia Memory, Library of Virginia, Richmond. http://www.lva.virginia.gov/chancery/case_ detail.asp?CFN=139-1853-013.

116. Chancery File Index (USA). Pickering v. Miller et al. Virginia Memory, Library of Virginia, Richmond. http://www.Iva.virginia.gov/chancery/case_detail.asp?CFN= 139-1853-013.

117. Chancery File Index (USA). Pickering v. Miller et al. Virginia Memory, Library of Virginia, Richmond. http://www.Iva.virginia.gov/chancery/case_detail.asp?CFN= 139-1853-013.

118. Chancery File Index (USA). Lucy Pickering v. Daniel D. Dovel. Virginia Memory, Library of Virginia, Richmond. http://www.Iva.virginia.gov/chancery/case_detail. asp?CFN=139-1864-006.

119. Census. 1850. USA. United States Federal Census. http://www.ancestry.com.

120. Gooden, Randall S. (1988) 'History and the interpretation of Appalachian culture: the case of the French Creek Region of Upshur County, West Virginia'. In: The Pioneer: Twenty-Sixth Report of the Descendants of the French Creek Pioneers. Buckhannon, W.V.: Ralston Press.

121. Hornbeck, Betty. (1967) Upshur brothers of the blue and the gray. Parsons, W.V.: McClain Printing Co.

122. Interview with George A. Gooden, Queens W.V., August 1968

123. State Historical Society of lowa. (1882) History of Davis County, lowa, containing a history of the county, its cities, towns, etc. Des Moines: State Historical Society. pp. 548-566.

124. Bureau of Census (USA). Population Schedules, 1870.

125. Department of Interior (USA). Bureau of Pensions, War of 1812 Pension Application Files. Record Group 15, National Archives and Records Admin., Washington, D.C.

126. Family Bible in possession of George A. Gooden.

ABOUT THE AUTHOR

Randall S. Gooden is an associate professor of History and the Jack and Sherry Hancock University Professor at Clayton State University in Morrow, Georgia, U.S.A., where he teaches family history and genealogy among other courses. He holds a B.A. degree in History, an M.A. in Public History, and a Ph.D. in History from West Virginia University.

Email: RandallGooden@clayton.edu 